Portland State University

PDXScholar

$5-19-1972$

\title{
Diagnostic congruence: a study on presentation of clinical information to parents and recall
}

\author{
Miriam Rae Maier \\ Portland State University
}

Follow this and additional works at: https://pdxscholar.library.pdx.edu/open_access_etds

Part of the Child Psychology Commons, and the Social Work Commons Let us know how access to this document benefits you.

\section{Recommended Citation}

Maier, Miriam Rae, "Diagnostic congruence: a study on presentation of clinical information to parents and recall" (1972). Dissertations and Theses. Paper 1577.

https://doi.org/10.15760/etd.1576

This Thesis is brought to you for free and open access. It has been accepted for inclusion in Dissertations and Theses by an authorized administrator of PDXScholar. Please contact us if we can make this document more accessible: pdxscholar@pdx.edu. 
AN ABSTRACT OF THE THESIS OF Miriam Rae Maier for the Master of Social Work presented May 19, 1972.

Title: Diagnostic Congruence: A Study on Presentation of Clinical Information to Parents and Recall.

APPROVED BY MEMBERS OF THE THESIS COMMITTEE:

Jack R. Hegrenes, Chatrman

Thelma Danilson

Curtis Weiss

The present study was an investigation of recall following presentation of diagnostic information. The setting was the Crippled Children's Division of the University of Oregon Medical School.

The purpose of the study was to test the hypothesis that one session conferencing imparting diagnostic information to parents of handicapped children reduces recall. Additionally, it was hypothesized that multi-discipline conferencing is related to greater diagnostic recall than single discipline conferencing. The sample was made up of 20 parent units whose children were evaluated at the Crippled Children's Division for suspected Cerebral Palsy and/or Mental Retardation. There were ten families from the Cerebral Palsy Clinic 
and ten from the Mental Retardation Clinic.

Three comparisons were made: (1) The amount of information presented at the staffing session was the baseline against which the amount of information imparted at the parent conference was compared. (2) The amount of information imparted at the parent conference was compared with the amount of information that was recalled six weeks later at the follow up interview. (3) The amount of information recalled at the time of the follow up interview was compared with the staffing information in order to determine the loss of diagnostic information.

The results supported the hypotheses. Diagnostic congruence was by far, more the exception than the rule. Implications suggest that additional follow up services are necessary. 
DIAGNOSTIC CONGRUENCE: A STUDY ON PRESENTATION OF CLINICAL INFORMATION TO PARENTS AND RECALL

$$
\text { by }
$$

MIRIAM RAE MAIER

A thesis submitted in partial fulfillment of the requirements for the degree of

MASTER OF SOCIAL WORK

Portland State University

1972 
TO THE OFFICE OF GRADUATE STUDIES:

The members of the Committee approve the thesis of Miriam Rae Maier presented May 19, 1972.

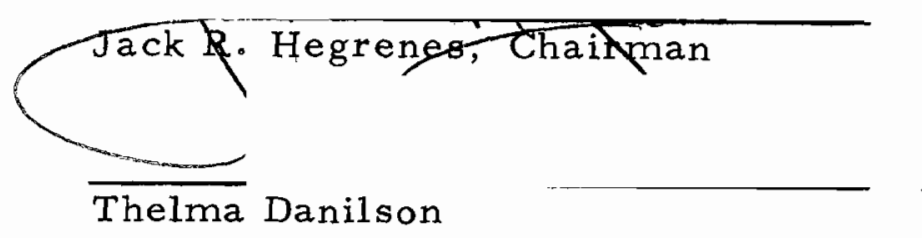

Curtis Weiss

APPROVED:

Gordon Heaxf Dean of the School of Social Work

David'T. Clark, Dean of Graduate Studies

May 19, 1972 


\section{ACKNOW LEDGEMENTS}

I would like to express appreciation to Richard Sleeter, M. D. , Director of the Crippled Children's Division and the staff who provided the opportunity for conducting this study.

Special recognition must go to Jack R. Hegrenes, Ph. D., Director of the Social Work Division who suggested the study and gave generously of his time in supportive guidance. His pleasant manner and encouragement sustained me through difficult moments.

For helpful references in the review of literature and for provocative questions, I give appreciation to Thelma Danilson, ACSW, social worker for the Cerebral Palsy Clinic.

Additional consultation was provided by Curtis Weiss, Ph. D., Speech Pathologist, in the area of statistical analysis, and for his contribution to the study I am indebted.

For innumerable suggestions and fragmented contributions, I extend general thanks to my colleagues and other professionally related friends.

Finally, I am deeply grateful for the unceasing patience, loyalty and support of my family; my husband, Ray, and our children, Andrea, David, Clarolyn and Joel. Great appreciation is due to Mrs. Betty Hopper ("Nana"), for her faithfulness and love in caring for the family during my absence. 
TABLE OF CONTENTS

Page

ACKNOW LEDGEMENTS

LIST OF TABLES

$v i$

LIST OF FIGURES

viii

\section{Chapter}

I THE PROBLEM

Statement of the Problem

The Study Hypothesis

II REVIEW OF THE LITERATURE

Presenting Information: Towards Patient

Awareness

Recall: Empirical Investigations

The Team Approach

III METHOD

IV FINDINGS

Intra-Clinic Comparisons

Cerebral Palsy Clinic

Mental Retardation Clinic

Inter-Clinic Comparisons

The Amount of Essential Staffing Information Imparted in the Parent Conference

The Amount of Recall from the Parent Conference

The Amount of Recall Compared to Essential Staffing Information 
Chapter

$\underline{\text { Page }}$

V SUMMARY

46

BIB LIOGRAPHY

48

APPENDIX

53 
I. Agencies Providing Services to the Mentally Retarded

II. Example of Information Units Designed for Each Discipline

III. Example of Determining Plus Values Based Upon the Example Shown in Table II

IV. Sample Value Rating

V. Example of Conversion of Plus Values Into Percentages, Using Subject Shown in Table II

VI. Example of the Percentage Value of Diagnostic Congruence by Individual Discipline (Medicine)

VII. Frequency Distribution of Baseline I Presented at Parent Conference (Baseline II)

VIII. Exact Subject Percentages of Baseline I Presented at Parent Conference

IX. Frequency Distribution of Percent of Baseline II Recalled Six Weeks Later

X. Exact Subject Percentages of Recall of Baseline II Six Weeks Later

XI. Frequency Distribution of Percent of Recall Compared with Baseline I

XII. Exact Subject Percentages of Recall Compared with Baseline I

XIII. Cerebral Palsy Clinic: Percent of Participation of Individual Disciplines in Clinic Sample. Percent of Baseline I Imparted at Parent Conference; Percent of Information Retained from Parent Conference and Percent of Information Retained, Compared with Baseline I 
XIV. Mental Retardation Clinic: Percent of Participation of Individual Disciplines in Clinic Sample. Percent of Baseline I Imparted at Parent Conference; Percent of Information Retained from Parent Conference and Percent of Information Retained, Compared with Baseline I 
viii

\section{LIST OF FIGURES}

$\underline{\text { Figure }}$

Page

1. Percent of Baseline I imparted at parent conference (comparison between clinics).

2. Percent of recall from Baseline II six weeks later (comparison between clinics).

3. Percent of recall compared to Baseline I (comparison between clinics).

4. Percent of recall information compared with Baseline I (comparison between clinics). 


\section{CHAPTER I}

\section{THE PROBLEM}

\section{STATEMENT OF THE PROBLEM}

This study in diagnostic congruence is related to the process of imparting diagnostic information to parents of children who have been evaluated at The Crippled Children's Division of The University of Oregon Medical School. The study also describes the amount of recall by the parents.

In spite of the theory in the literature which warns the professional clinician that much of the initial diagnostic communication may be screened out by the patient, some professionals continue to operate on the assumption that one post diagnostic session suffices. Often, there may be follow up visits pertaining to management aspects but apparently little concern for follow up in order to impart diagnostic information per se. Questions might be raised concerning the degree of parental understanding of diagnostic data. Accordingly, the opportunity to study parents in various clinics at The Crippled Children's Division regarding their understanding of the diagnostic results from their child's evaluation seems relevant. It would be of 
great interest to determine the process by which the diagnostic data was imparted to the parents and how much the parents remembered after a short time interval. If great differences were found between the amount of information imparted to the parents and the amount which they remembered following the conference, it would be a strong case for the inadequacy of one session conferencing.

From the point of view of social work practice, questions could be raised about the need of the se parents for additional services. Recognizing the variance in social, mental and emotional factors of individual personalities, one may conclude that the mere imparting of diagnostic findings and therapeutic recommendations is not an end in itself but only a progressive step toward a desired end. Witmer and Katinsky (1952) make reference to the unique relationship of the family to the expert who possesses the scientific knowledge and who understandably is a threat to the parents who, after all, are the constant environment in a child's life and whose responsibility it is to allow the helping process to take place within the family unit. It fol lows, that the expert cannot afford to lose sight of the fact that only the family can accept full responsibility for the child. This distinction presents a challenge for the professional to assume an holistic approach in his dealings with the family; that is, to see man in his totality of being and to bridge the communication gap by which the patient is held a prisoner. 
Where there is an all-pervading wish for the parents to hear that their child is normal, there is also an evolving awareness that their worst fears may be confirmed. The resulting stress places such demands upon their coping mechanisms that, very often, the situation cannot be handled without assistance. The preoccupying longing for one's child to be normal is the figurative fog which must be cleared in order to facilitate the adaptive and reorganization processes of the parents'thoughts, emotions and actions.

Helen Beck (1959) points out that diagnosis needs to be focused upon the total situation to include the medical, social and psychological diagnosis of the child's condition, needs of the family unit, parents' personalities and their ability to use available services.

\section{THE STUDY HYPOTHESIS}

Based upon the assumption that parents of children with suspected or actual handicaps retain diagnostic information in accordance with their individual capacities to intellectually perceive, emotionally accept and functionally respond, it was hypothesized that the mere imparting of diagnostic information was in itself an incomplete process. It was expected that in addition to one parent conference, follow up therapeutic methods and techniques are necessary for the emotional healing and rebabilitation of the patient and also his family.

The study hypothesis is two fold in nature. 
1) A single post diagnostic conference is related to a great loss in diagnostic understanding which implies the need for additional follow up services. Based upon the assumption that additional follow up services are necessary to the parents' best understanding of diagnostic information, it would seem appropriate for a number of these services to be provided by the representative of the social work discipline.

2) Multi-discipline conferencing results in greater diagnostic understanding than single discipline conferencing, however, in a medical setting, it is probable that medical content is highlighted more than that of other disciplines. 
CHAPTER II

REVIEW OF THE LITERATURE

\section{PRESENTING INFORMATION: TOWARDS PATIENT AWARENESS}

A review of the literature in the areas of learning, memory, forgetting, retention, perception, recall, patient education, etc. reflects a common message that a significant amount of imparted information has not been heard, understood or retained. Essential to providing adequate professional services is the establishment of a working relationship between the professional and the lay person.

Tudway (1970) in dealing with the precarious family unit, described the importance of establishing trust as a priority in the doctor-patient relationship. Having established trust, he was successfully able to lead a fearful and resistant patient through a necessary the rapeutic process.

Oldham (1970) evaluated the professional's frequent avoidance behavior when one is faced with hopless cases. He may inadvertantly tend to reject the patient, i.e., in the case of a terminal cancer patient, the physician may resort to the ego defense of denial by telling the patient that he has a growth or mass instead of using the word, 
cancer. 2) Accidentally forget to see the patient on rounds, and 3) finally, in overt rejection, move to a "more interesting case." The phenomenon of premortem burial may occur, which is characterized by an unnatural attitude toward the patient and avoidance of verbal contact, the sequence the patient fears most. The physician who allows the patient to verbalize can do much to ameliorate the suffering of the hopeless patient. A four-fold resolution is suggested in the handling of such cases; 1) education, 2) communication, 3) attention and 4) realism. Although Oldham (1970) was concerned with the terminal cancer patient his points may be taken advisedly by those disciplines which are faced with helping clients through hard-to-bear situations. He quoted Hugh J, Morgan M.D.

Let us act with authority and responsibility and also with compassion and understanding and restrained subtle sympathy. A. cheerful demeanor, patient attention, avoidance of a hopeless attitude or of indifference and encouragement by attitude and indirection. They sustain and support the spirit of his battle.

Lemkau (1961) pointed out that a quality of compassion is necessary however, it requires an accompanying of scientific findings and interpretations in order for knowledge and informed theory to keep compassion working at maximal efficiency.

With regard to professional awareness, Jannis (1970) advised that careful examination of the patient's communications reveals components which allow one to estimate the degree to which the professional's interventions are precisely responsive. 1) The patient's 
mature efforts to understand himself must be recognized and encouraged and not confused with resistances and defenses. 2) The patient's justified request for help in furthering his understanding must be met and not confused with neurotic demands. 3) The patient's neurotic reactions of disappointment and anger and his exaggerated neurotic fears must be consistantly and accurately interpreted. Clinical experience has suggested that patient's valid need for therapeutic intervention is too often unmet.

Parents of children with special problems need and want, in varying degrees, 'help and advice!' (Laurence, Payne and Rawnsley, 1966). In their study of 97 cases, one-third of the mothers expressed a wish for more services, with particular emphasis on empathy. They wanted to hear words of comfort which would have indicated under standing and sympathy on the part of the professionals.

It follows that anger and disappointment may take the form of those patients described by Silberstein (1970) as uncooperative. This label, assigned by the doctor, may be due to the physician's own failure to communicate that which he desires the patient to do; may be using words that the patient does not understand; may be in a hurry, failing to allow for questions. The patient may be mentally dull and have difficulty understanding his physician or he may be actually demented and finally, he may be frightened and respond with anger. Whatever the case, the professional must be prepared to cross 
examine his own and the patient's feelings if he is truly to care for the patient.

According to Beck (1959), parents tend to reject painful information that comes from a seemingly uninterested or unfeeling source. Much frantic shopping around in connection with chronic conditions may be caused by the tendency on the part of the clinician to short-cut the diagnostic process.

The need to deal with stress and anxiety in the parents of defective children whether it be a case of mental retardation, spina bifida cystica, cerebral palsy, etc., is emphasized by several authors (Zwerling, 1954; Hare, 1969; Hare, Laurence, Payne and Rawnsly, 1966). Counseling in such cases demands multiple contacts and should not be attempted in a single conference.

Doll (1953) advised that when a parent requests consultation, the most significant part of the diagnosis has already been accomplished, i.e., in the case of suspected mental retardation, consultation is really directed toward 1) How severely retarded is my child?, 2) What kind of person is he?, 3) Is he some particular clinic type?, 4) What is the prognosis?, and 5) What as a parent should I do about it? .

Letha Patterson, a mother of a retarded child and member of the National Association for Retarded Children compiled some insights which came her way from both professional workers and parents out 
of which came the following pointers for professionals. (1) Tell us the nature of our problem as soon as possible. (2) Always see both parents. (It is difficult for one parent to restate and interpret a problem not clearly understood by that parent. Parents need to be led together in their understanding and acceptance of the problem.)

(3) Watch your language. (Avoid extremes of professional terms and also common words of the obnoxious variety like "idiot" or "feeble minded.") (4) Help us see that this is our problem. (Avoid taking the problem over for us. Include us in the planning.) (5) Help us to understand our problem by recommending reading material; multiple conferencing; putting us in touch with an association for retarded children; and, talking with other parents of retarded children.

(6) Know your resources. (7) Never put us on the defensive.

(8) Remember that parents of retarded children are just people with a serious problem, a great sorrow--a living sorrow. (9) Remember that we are parents and you are professionals, i.e., do not in front of us: belittle the opinion of your professional partner; make critical remarks about other parents; jump to conclusions about our case; or, try to do a job that is outside your professional discipline. (1) Remember the importance of your attitude towards us. We expect you to be objective about our problem but never about us. We need 'loving kindness" and "empathy." "If you can help us convert our problem into good for mankind you will find a far more precious jewel in your 
professionalism than you ever thought existed" (Patterson, 1956, p. 17).

Parental attitudes toward child rearing of both normal and defective children are significant to the counseling process.

Shaefer and Bell (1957) suggested that parental attitudes are related to the social and emotional adjustment of children. He listed five independent factors to consider in assessing parental attitudes;

1) interpersonal distance, 2) rejection of homemaking role,

3) excessive demands for strivings, 4) over permissiveness and

5) hostile punitive control. Other authors adding empirical substance to the effects of parental attitudes upon the developmental process are Garfield and Helper (1962), Block (1955), Schaefer (1958), Zucherman (1960) and Zucherman (1960a).

\section{RECALL: EMPIRICAL INVESTIGATIONS}

Murdock (1960) and Mudrock and Babick (1961) empirically substantiated the effectiveness and associative bond in the learning process. Murdock (1961) in a study of multitrial free recall was able to modify rather considerable recall performance by using interactive presentation on the basis that each trial constituted reinforcement. Additional empirical data to support that meaningful repetition enhances learning was found in research done by Reynolds and Glaser (1965), Ausubel and Youssef (1965) and Wike and Wike (1970). 
King and Schultz (1960) found in studying recall of stories read that the meaningfulness of the material increased the degree of learning .

Baron (1962) and Strupp (1969) found statistical significance in their studies that emotional involvement is related to learning and that therapeutic learning is maximally effective when emotions have been positively mobilized.

Auditory interference in studies done by Mowbry (1964) and Parker (1969) substantiated that recall is limited by interference and they also confirmed the validity of the concept that man's perceptual system is basically a single channeled one with a limited informationhandling capacity.

An experimental investigation on memory and comprehension of news content in daily radio broadcasts was done by Adruzzinini, Anfossi, Ferracuti, Lazzari and Zacone-Derossi (1965). The data was collected by interview $(N=120)$ and the results indicated that 40 percent of the news material was recalled. International news recall ranked significantly higher than local news items. The amount of material recalled was highly correlated with vocabulary and cultural level but only slightly correlated with performance on the memory test which had been administered to each subject.

Marshall (1967) in measuring the effects of diagnostic consultation on maternal evaluation of speech behavior of handicapped 
children found a remarkable absence of studies concerning the manner or results of utilizing diagnostic findings as an integral part of continuing consultation with parents. Additionally, it was found that the use of visual aids increased understanding of diagnostic information.

Studies that support the inaccuracy of recall were undertaken by Goddard (1961) and Wenar (1962). Goddard's (1961) sample of 25 mothers who were asked to recall pediatric histories several years following infancy. These were compared with hospital clinic records in order to determine the divergence of the two sources. The results revealed many discrepancies. Wenar's (1962) study sample of 60 mothers were asked to recall developmental histories of their children. He found a tendency on the part of the mother to 1) make the children look precocious 2) distort according to socially acquired concepts and 3) picture family life in conformity to cultural stereotypes. Two important variables were 1) the affective content of the event being recalled and 2) the mother's emotional state.

Patient centered teaching should be concomitant to diagnostic consultation. Sensitivity to patient's abilities and experience in helping them to cope with difficulties in their environment are the focus of Aiken's (1970) paper.

A study concerning patients perceptions of their cognitive needs was conducted by Dodge (1969) in which he found that patients were particularly concerned with receiving the kinds of information which 
would enable them to plan realistically in their immediate and long range lives. Their major questions were directed toward the solution of the very real problems which their illness imposed.

The two foregoing studies are empirical reminders of the human incapacities and biases that need to be considered by the helping professions, particularly where client understanding is essential to the rehabilitation process. The process of helping patients solve their own problems includes more than the obvious teaching areas (Aiken, 1970). It becomes a continuous process of helping patients to cope with the difficulties in their environment and in doing so they are helped to utilize their coping mechanisms more effectively. Dodge (1969) in a rather elaborate experiment, studied patients' perceptions of their cognitive needs. One hundred and sixteen hospital patients were interviewed and measured on thirty two items of information. In summary, it was found that patients were particularly concerned with receiving the kinds of information which would enable them to plan realistically for their immediate and long range needs. Their major questions were directed toward the solution of the very real problems which their illness imposed. They were not concerned with knowing things that would not materially contribute to their understanding of their condition or its effects on their lives.

That effective diagnostic consultation is essential to successful adaptation on the part of the patient and his family, is alluded to by 
numerous authors in terms of the stress with which families must deal when faced with the unexpected responsibility of caring for a handicapped child.

Olshansky (1962) defines the reaction to such trauma as chronic sorrow, a grieving which is common to tragic life situations.

Rapoport (1962) and Shotland (1964) describe various responses to the stress brought on by having produced an imperfect child. Some of the most common feeling responses which plague the parents are fears about future pregnancies, guilt (particularly if the defective child was an unwanted pregnancy); resentment about not understanding why such a tragedy should strike; and, uncertainty about health care and management.

Ferguson and Tweed (1971) studied a group of 50 families with stress related to the care of children with myelomeningocele. It can be generalized from the findings of that study that parents with chronically handicapped children are faced with an unusual number of potentially stressful situations during their child's life span, thus requiring many post-diagnostic sessions and support from the community to aid the family in maximizing the health care and social needs unique to the traumatized family. 


\section{THE TEAM APPROACH}

The setting for the present study utilizes and/or exemplifies the team approach. Actually, the term consortium may be more appropriate to the setting because of the interdependence and physical proximity of the participating disciplines. The frequency of the need for multiple fragmented services demands an integration of those services.

In a study of generic services for the mentally retarded and their families, Scheerenberger (1970) asked 504 representatives of various generic services including medicine, guidance and counseling, religion and socio-recreational services to identify problems associated with serving the mentally retarded person and his family. Two common problems emerged: 1) communication and 2) finding sufficient time to provide required services. (Very few were associated with serving the mentally retarded patient.) The study also included 232 parents from the same socio-economic areas who were asked to determine commonalities of their experience with the professionals. The results were 1) lack of community resources, 2) inferred on the basis of parent responses that parents must have access to a program of guidance and counseling which will assist them in making decisions concerning their retardate at each stage of life.

Appropriate to the present study is Stephen's (1969) article in 
which he compares two approaches in interpreting mental retardation to parents in a multidiscipline diagnostic clinic. One of the most revealing processes which reflect the quality of the diagnostic clinic operation is the method of interpreting handicapping conditions to parents. This is true for several reasons: it reflects the self image of the staff; it is indicative of the perceptiveness of the policy makers; and, it reveals the diagnostic procedures at one of its most critical points--the intersection of the total diagnostic procedure with the demands and needs of its clientele.

Two models of imparting diagnostic information were described in the above study. First, was the "virtuoso model." In this model, a group of highly trained medical and paramedical specialists assemble with the objective of providing services of the highest quality. The director is usually a physician. Professional persons from the community are invited so that they may see for themselves the comprehensive nature of the program. Each discipline shares its information from detailed examinations and a conclusion is reached about etiology and prognosis. Then the parents are brought into the conference room and assured that the group is interested in their child, "a statement which would certainly reassure rational parents anywhere" (Stephen, 1969, p. 58). The results of the diagnostic study are explained to the parents and the conference is over. "The professional visitors go away, impressed by the perceptiveness and 
diagnostic acumen of the clinic staff, exclaiming under their breath. The parents and child just go away" (p. 58).

Second, was the "interaction model" which assumed that parents are not impressed by a collection of professional workers. Another assumption was that parents receive little edification from hearing detailed reports of laboratory findings, etc. A third assumption was that several interpretation sessions with parents are far more effective than one session, both in imparting information and investing professional time. It was suggested that the interaction point of view should proceed along the line of questioning raised by the parents rather than following some prescribed outline developed by diagnostic staff. This model cannot be dealt with in a single session and may seem wasteful of staff time, however, two points indicate that efficiency and effectiveness of such an approach. First, parents are better able to accept the interpretation of the problem when it is discussed over a period of time rather than at one sitting. Second, the apparent time saving of a single session is offset by later telephone calls from the parents for additional information from various staff members and other continued efforts by parents to gain information which should have been provided in the first place. The author defended the "interaction model" as being superior to the "virtuoso model" because it provides for prolonged contacts with parents; interpretation follows the parents line of questioning; and, it attempts 
to deal with underlying concerns rather than superficial ones.

Pearson and Menafee (1965) compiled an elaborate system concerning the medical and social management of the mentally retarded. Table 1 lists a run down of the various agencies which are involved in the solution of the multi-faceted problems of the mentally retarded. This is an evincing document focused on the need for the physician to use allied professions and agencies in coordinating comprehensive medical, psychologic and social evaluations and services for these patients. It is the bias of the researcher that social work practice is one of the most essential of the allied professions not only in dealing with the handicapped person and his family, but also in coordinating helping services.

In the American Association Handbook, Mental Retardation, Covert (1965) cited that the prime task of social services is to relieve social stress. It suggested that the physician may call on a range of social services, including parent counseling, home training, management services; preschool and day care, homemaker's and babysitting services, camping and group recreation, religious guidance, adoption and residential care. The use of these services will depend upon the physician's appreciation of their function and his alertness to the needs of the individual. The trained social worker is skilled in collecting social information helpful to accurate diagnosis. For purposes of this study, an additional point to consider is the utilization of social 
TABLE I

AGENCIES PROVIDING SERVICES TO THE MENTALLY RETARDED

Service

Agency

\section{Diagnosis and special treatment}

Homemaker services

Day care

Special education classes

Sheltered workshops
Vocational training and employment

Foster care

Residential care

Financial assistance
Child health clinics, special child development clinics, medical school clinics, mental health clinics, crippled children's clinics, neurologic clinics

County welfare departments, health departments, private family casework agencies Local Associations for Retarded Children, United Cerebral Palsy Association chapters, churches, Neighborhood House Association, community centers

Public schools

Goodwill Industries, local Associations for Retarded Children, United Cerebral Palsy Association chapters, Jewish Vocational Service, state divisions of vocational rehabilitation

YMCA, YWCA, YMHA, Boy Scouts, Girl Scouts, Camp Fire Girls, local Associations for Retarded Children, city recreation departments, community centers, churches

Public schools, state divisions of vocational rehabilitation, state employment service, Jewish Employment Service, county welfare departments, Salvation Army

County child welfare agencies, Family and Children's Service, Lutheran Welfare Service, Catholic Social Service, Jewish Family and Children Services, children's home societies

State institutions, private institutions, children's home societies, hospitals, residential schools

County or city welfare departments, Social Security Administration, Veterans Administration, Catholic Charities, Jewish Family and Children Services, Lutheran Social Services 
work skills beyond the single parent conference. The social worker's "techniques include expert interviewing, observation of the child in various settings, assessment of the home environment and family resources; and coordination of findings by other disciplines and agencies" (p. 72).

Collaboration between the physician and the social worker can be helpful in facilitating patient planning and management.

Gang (1971) found in his experiment of combined learning between the social worker and physician, that he learned facts about the patient with which he had never been acquainted and learned points of view to which he had not been introduced in his medical training. Another finding was the relief of frustration of seeing patients in distress whom he was unable to help through lack of time, training and contact with the utilization of appropriate social services.

Lang and Oppenheimer (1968) studied the influence of social work when parents are faced with the fatal illness of a child. The initial reaction, of almost all parents to the knowledge that their child had a fatal illness, created a state of crisis and despiar. The experience was usually so stressful that the demands on their coping mechanisms could not be handled without assistance. The study demonstrated that the provision of social work help, applied with appropriate intensity in relation to speed, enabled most of the subjects to endure the stress without being destroyed by it. Hegrenes' (1970) 
study of the effects of early institutionalization on adult functioning makes a case for the strength and resiliency of the human organism, however, restitutive efforts seem necessary to reversing adverse experiences.

The process of rehabilitating a handicapped person usually requires the utilization of multiple health services. With regard to the need for integration of services, the following statement was made at the National Conference on Homemaker Services (1964).

A series of independent services means a series of possible chasms into which the patient can fall and from which he must be rescued with all the extra expenditure of effort and resources that the crisis demands.

The uniqueness of Social Work's ancillary roles in relation to other helping professions should be an enabling force in implementing effective servicing. Social casework is "a process used by certain human welfare agencies to help individuals to cope more effectively with their problems in social functioning" (Perlman, 1957, p. 4), It consists of a series of problem solving operations carried on within a meaningful relationship. In this process the social worker "must grasp the nature of the person who is a client, the nature of his problem and the nature of the place which contains the problem solving means"! (p. 4).

In reference to coordinated health services, more than a suggestion is implied by Wallace (1958) in the following quote.

Where there is no joint planning and coordination among the services for handicapped children, continuity of care is not always provided.. . not all children receive all the services they need at the time most appropriate for them (p. 21). 


\section{CHAPTER III}

\section{METHOD}

The Crippled Children's Division is the designated agency for administration of federal-state programs for Crippled Children's Services.

It is important to understand the specific nature of the Crippled Children's Division and the role it takes in relation to handicapped children in the state of Oregon. The agency has a manditory obligation to serve all areas of the state. The primary goal is to offer diagnostic services and treatment resources to the handicapped child. This is to insure, that whenever possible, all handicapped children in the state of Oregon are given a chance to reach adult life and take their place in society as well adjusted and self-sustaining citizens. The age group served is from birth to 21 years of age. Individuals with long term chronic handicaps are seen periodically and help is given with planning and integration of all service needs. Social work services are particularly necessary to those patients who are chronically handicapped and for whom long term treatment will be required. 
A unique and important component of service programs is the team evaluations and consultation to physicians and other personnel in the community. The makeup of the multiple discipline team varies depending upon the nature of the individual clinic. The professions include medicine, social work, speech pathology, audiology, psychology, nutrition, nursing, dentistry, physical and occupational therapy, education and ophthalmology. The team composition in each clinic is somewhat different, i.e., the opthalmologist is used in the Cerebral Palsy Clinic for examining patients, however, that discipline is not present at the staffing. His findings are presented at the staffing only if a team member request his report. Education is a key dis cipline in the Mental Retardation Clinic but used only upon request by the Cerebral Palsy Clinic. The same arrangement applies to Nursing and Nutrition.

The Mental Retardation Clinic assigns a case coordinator to each case. The functions of the coordinator are to preside over the staffing session, the parent conference, and to maintain necessary contacts with parents. The Cerebral Palsy Clinic has no "case coordinator." Presumably, the Medical Director for that clinic attempts to fill that role.

A striking difference between clinics is the method of parent conferencing. The Mental Retardation Clinic routinely includes the case coordinator and those disciplines most involved in the diagnostic 
process. In the Cerebral Palsy Clinic, parent conferencing is routinely done by the pediatrician. Other disciplines participate on occasion only at the invitation of the medical discipline. An exception is the social worker who attempts to involve herself where time permits attention to those cases most in need of social work services.

The subjects used in this study were 20 parent units, each of which had one or more children who were evaluated by multidiscipline teams of The Crippled Children's Division of The University of Oregon Medical School in Portland. There were two sample groups: 1) Ten parent units from The Cerebral Palsy Clinic and ten from the Mental Retardation Clinic. The criteria in selecting these parents were 1) that the children had been accepted for evaluation due to sus pected cerebral palsy and/or mental retardation. The families were selected in consecutive order according to clinic schedules beginning July 1971 and observations were done at the rate of two parent units each week. The only exclusions were those families whose residences were outside the Portland Metropolitan area. The sample was not randomly selected.

The design used for this study was a "one-shot case study" (Campbell, 1957, p. 297). The design is one in which a single individual or group is studied in detail only once, and in which the observations are attributed to some prior situations. Two sample groups were observed once each following situation exposure, the 
exposure being a conference in which the parents of the children who had been evaluated were given verbal information relative to the diagnostic findings and the treatment recommendations.

The collection of the data was divided into three parts.

1) The team staffing of the case

The teams were representative of the following disciplines: dentistry, education, neurology, nursing, nutrition, occupational therapy, psychology, ophthalmology, orthopedics, pediatrics, physical therapy, social work, speech pathology, and audiology. It was the procedure of the clinics for the participating disciplines to meet as a team immediately following the examination process to present findings, evaluate for diagnosis and formulate recommendations for the treatment plan. The researcher attended each staffing and recorded, in full, the reports of each discipline, the discussion of the findings, diagnosis and recommendations, and the final recommendations agreed upon by the team.

\section{2) The Parent Conference}

The parent conference was conducted immediately following the team staffing in order to share with the parents by verbal report, that information which was related to the team's findings, diagnosis and treatment recommendations. For purposes of the present study, two approaches of imparting information to the parents were observed. 
1) Multi-discipline conferencing, employed by the Mental Retardation Clinic

2) Single-discipline conferencing, used by Cerebral Palsy Clinic

The researcher observed each of the parent conferences and recorded in full that information imparted to the parents by the team representatives. It was at the time of the parent conference that the researcher was introduced to the parents as a social worker who would be contacting them in six weeks for a follow-up visit.

\section{3) The Follow-up Interview}

Six weeks from the time of the parent conference, each parent unit was interviewed for the purpose of gathering that information which had been retained from the parent conference. Refreshing the memory of the parent by mentioning the participating disciplines was helpful to the researcher in assessing more accurately the recalled data than were generalized questions. For example, in generalized questioning it was not uncommon for the parent to draw a blank or make a generalized statement such as "they said he was O.K." or "she'll always be behind." Responses to mentioning individual disciplines were more spontaneous and specific. For example, "occupational therapy suggested that I should let him do more for himself" or "oh yes, he is supposed to be checked again by the orthopedist." For identification purposes, the information which was presented 
at the team staffing session was called baseline I. The information presented at the parent conference was called baseline II. The information obtained from the parents six weeks later was referred to as recalled information. For purposes of statistical analysis, the information was condensed into information bits based upon the researcher's subjective judgement in terms of quantitative and qualitative values. A bit was defined as a significant specific segment of information. The total number of bits associated with a particular discipline and a given session was classified as an information unit. An example of this is shown in Table II.

The information units of the parent conference and follow up interview sessions were converted into plus and minus values depending upon the quantitative and qualitative evidence of communication. If 75 percent of the information in the staffing (Baseline I), was given in the parent conference (Baseline II), the parent conference was given a plus value. If less than 75 percent was presented in the parent conference, a minus value was given. The six weeks follow up session with the parents to determine the amount of recall from the parent conference was given a plus value if 75 percent of the information from the parent conference (Baseline II) was recalled. If less than 75 percent was recalled from the parent conference, the six weeks follow up interview was given a minus value. It is important to remember that a plus in the follow up interview is compared to the parent 
EXAMPLE OF INFORMATION UNITS DESIGNED FOR EACH DISCIPLINE

\begin{tabular}{|c|c|c|c|}
\hline Discipline & Baseline I & Baseline II & $\begin{array}{c}\text { (Recall Compared to } \\
\text { Baseline II }\end{array}$ \\
\hline \multirow[t]{6}{*}{ Medicine } & $\begin{array}{l}\text { 1. No health problems } \\
\text { (except). }\end{array}$ & $\begin{array}{l}\text { 1. No health problems } \\
\text { (except). }\end{array}$ & 1. In good health (except). \\
\hline & 2. Obesity. & 2. Obesity. & 2. Ove rweight. \\
\hline & $\begin{array}{l}\text { 3. Consult with family } \\
\text { physician for obesity. }\end{array}$ & $\begin{array}{l}\text { 3. Consult family } \\
\text { physician for obesity. }\end{array}$ & $\begin{array}{l}\text { 3. Consulting family } \\
\text { physicial not recalled. }\end{array}$ \\
\hline & $\begin{array}{l}\text { 4. Considering present age } \\
\text { and weight, should not } \\
\text { gain for } 3 \text { years. }\end{array}$ & $\begin{array}{l}\text { 4. Considering age and } \\
\text { weight, should not } \\
\text { gain for } 3 \text { years. }\end{array}$ & $\begin{array}{l}\text { 4. Should not gain weight } \\
\text { for next } 3 \text { years. }\end{array}$ \\
\hline & $\begin{array}{l}\text { 5. Has nasal noise but } \\
\text { not serious. }\end{array}$ & 5. Has nasal noise. & 5. Nasal noise not serious. \\
\hline & $\begin{array}{l}\text { 6. Expect nasal noise to } \\
\text { improve in time } \\
\text { without treatment. }\end{array}$ & $\begin{array}{l}\text { 6. Will improve in time } \\
\text { without treatment. }\end{array}$ & $\begin{array}{l}\text { 6. Will outgrow nasal noise } \\
\text { in time. }\end{array}$ \\
\hline \multicolumn{4}{|l|}{ Total } \\
\hline $\begin{array}{l}\text { information } \\
\text { bits }\end{array}$ & 6 & 6 & 5 \\
\hline
\end{tabular}


conference, (Baseline II) not to the staffing information, (Baseline I). The qualitative value of the information was also a determining factor which could influence the total value of the information unit. For example, if a subject recalled three out of four bits of information but forgot a very important bit which might be the most significant, the information unit would be given a minus value.

The plus and minus values were dependent upon whether or not those qualitative and quantitative criteria were met. An example of determining plus values is shown in Table III which is based upon the numerical values shown in Table II.

TABLE III

EXAMPLE OF DETERMINING PLUS VALUES BASED UPON THE EXAMPLE SHOWN IN TABLE II

\begin{tabular}{lccc}
\hline Discipline & 1 & 2 & 3 \\
\hline Medicine & $6=+*$ & $6=+$ & $5=+$ \\
\hline$*$ Ths plus value for column l indicates that the disci- \\
pline participated in the evaluation, providing baseline \\
I.
\end{tabular}

For each subject, the number of pluses from the information units of each session column were totaled. An example of one subject is shown in Table IV. The ratios of the plus totals were then converted into percentages, i.e., by computing the total number of pluses 
in column 1 against those in column 2 .

TABLE IV

SAMPLE VALUE RATING

\begin{tabular}{|c|c|c|c|}
\hline Discipline & $\begin{array}{c}\text { Baseline } \\
\text { I }\end{array}$ & $\begin{array}{c}\text { Baseline } \\
\text { II }\end{array}$ & $\begin{array}{c}\text { Recall Compared } \\
\text { to Baseline }\end{array}$ \\
\hline Medicine & + & + & + \\
\hline Social work & + & - & $+*$ \\
\hline Speech and audiology & + & + & - \\
\hline Opthalmology & + & + & + \\
\hline Occupational therapy & - & - & - \\
\hline Physical therapy & + & + & + \\
\hline Psychology & + & + & + \\
\hline Neurology & - & - & - \\
\hline Orthopedics & - & - & - \\
\hline Dentistry & + & - & - \\
\hline Nursing & - & - & - \\
\hline Education & + & $t$ & + \\
\hline Nutrition & - & - & - \\
\hline Recommendations & + & + & + \\
\hline Plus Totals & 9 & 7 & 7 \\
\hline
\end{tabular}

The subject used as an example in Table IV is also used in Table $\mathrm{V}$, which demonstrates the conversion of plus values into percentages.

1) The amount of Baseline I information that was imparted at the parent conference, (Baseline II).

2) The amount of recall compared with Baseline II.

3) The amount of recall compared with Baseline I. 
TABLE V

EXAMPLE OF CONVERSION OF PLUS VALUES INTO PERCENTAGES, USIIVG SUBJECT SHOWN IN

TABLE II

\begin{tabular}{lcc}
\hline $\begin{array}{c}\text { Percent of Baseline I } \\
\text { Compared to Baseline II }\end{array}$ & $\begin{array}{c}\text { Percent of Baseline II } \\
\text { Recalled in Follow-up } \\
\text { Interview }\end{array}$ & $\begin{array}{c}\text { Recall Compared } \\
\text { to Baseline I }\end{array}$ \\
\hline$\left(\frac{7}{9}\right)=78 \%$ & $\left(\frac{7}{7}\right)=100 \% *$ & $\left(\frac{7}{9}\right)=78 \%$ \\
\hline The percent of information shown in column 2 reflects a percentage \\
of Baseline II, not Baseline I.
\end{tabular}

Additionally, a comparsion of the effectiveness of communication was measured for each discipline in each clinic. The baseline for measurement depended upon whether or not a discipline was a participating member of the team for a given subject. For example, if the medical discipline participated in the total number of staffings for each clinic; that discipline represented a 100 percent value. If that discipline was included in the information presented at the parent conference of eight subjects, that discipline was given an 80 percent value. It follows that if in the follow up interviews, only five parent units were able to recall the information related to that discipline, it would result in a 50 percent value. An example of one discipline is shown in Table VI. 
TABLE VI

EXAMPLE OF THE PERCENTAGE VALUE OF DIAGNOSTIC

CONGRUENCE BY INDIVIDUAL DISCIPLINE (MEDICINE)

\begin{tabular}{lcccc}
\hline Discipline & Baseline I & Baseline II & $\begin{array}{c}\text { Recall from } \\
\text { Baseline II }\end{array}$ & $\begin{array}{c}\text { Recall Compared } \\
\text { to Baseline I }\end{array}$ \\
\hline Medicine & $100 \%$ & $100 \%$ & $80 \%$ & $80 \%$ \\
\hline
\end{tabular}

The amount of diagnostic information given in the staffing was compared to the amount of information which the parents remembered. In order to further demonstrate the amount of information lost, parent recall was also compared to the amount of information given in staffing. This part of the study was descriptive, The above comparisons were made within each clinic.

Additional comparisons were made between the Cerebral Palsy Clinic and the Mental Retardation $\mathrm{Clinic}$. Three comparisons were made between the clinics: (1) the percentage of information given to the parent from the staffing, (2) the percentage of information which the parent remembered from the conference, (3) the percentage of information recalled by the parent from the staffing which the parent did not, of course, attend. The comparisons between the Cerebral Palsy Clinic and the Mental Retardation Clinic were anlayzed statistically, using the standard t. Although the cases were not randomly selected, it could be argued that the ten cases selected in each clinic 
were representative of the patients seen at the Crippled Children's Division. In addition, ten cases would represent 20 percent of the total possible cases seen at the Crippled Children's Division in a particular year for the clinics selected for the study. 


\section{CHAPTER IV}

\section{FINDINGS}

\section{INTRA-CLINIC COMPARISONS}

\section{Cerebral Palsy Clinic}

The amount of staffing information that was determined to be essential for the parent conference and actually imparted for the ten cases was 42.5 percent. Accordingly, the physicians who transmitted the staffing information in the parent conference presented less than half the information which was determined to be essential $\overline{(X}=42.5$, $s=18.791$.

The follow up interview six weeks later indicated that they recalled only 42.6 percent of the information from the parent conference $(\bar{X}=42.6, \quad s=33.34)$.

When a comparison was made between the information considered essential in the staffing and the parent's recall, the informational loss is even greater. The parents only retained 19.8 percent of the essential information $(\bar{X}=19.8, s=21.16)$. 


\section{Mental Retardation Clinic}

The amount of staffing information that was determined to be essential for the parent conference and actually imparted for the ten cases was 73.80 percent. Accordingly, the multi-discipline team who transmitted the staffing information in the parent conference presented about three-fourths of the information which was determined to be essential $(\bar{X}=72.80, s=17.13)$.

The follow up interview with the parents six weeks later indicated that they recalled 71.30 percent of the information from the parent conference $(\bar{X}=71.30, \quad s=27.59)$.

When a comparison was made between the information considered essential in the staffing and the parent's recall, the information loss was even greater. The parents retained only about one-half of the essential information $(\bar{X}=53.80, s=22.46)$.

\section{INTER-CLINIC COMPARISONS}

The Amount of Essential Staffing Information Imparted in the Parent Conference

A comparison was made between the Cerebral Palsy Clinic and Mental Retardation Clinic for the percentage of information considered essential in the staffing and imparted in the parent conference. The major difference in these two clinics in parent conferencing was the 
use of only a physician in the Cerebral Palsy Clinic and a multidiscipline team in the Mental Retardation Clinic. The difference between single discipline conferencing in the Cerebral Palsy Clinic and the multi-discipline conferencing in the Mental Retardation Clinic was statistically significant $(t=3.699, \mathrm{df}=18, \mathrm{p}<.01)$.

A frequency distribution of the amount of information imparted between the two clinics is shown in Figure 1 . The frequency distribution of the percent value for each subject is listed in Appendix B (Table VII). The exact percentages for each subject is shown in Appendix B (Table VIII).

The results showed that multi-discipline conferencing imparted a much higher percentage of essential staffing information.

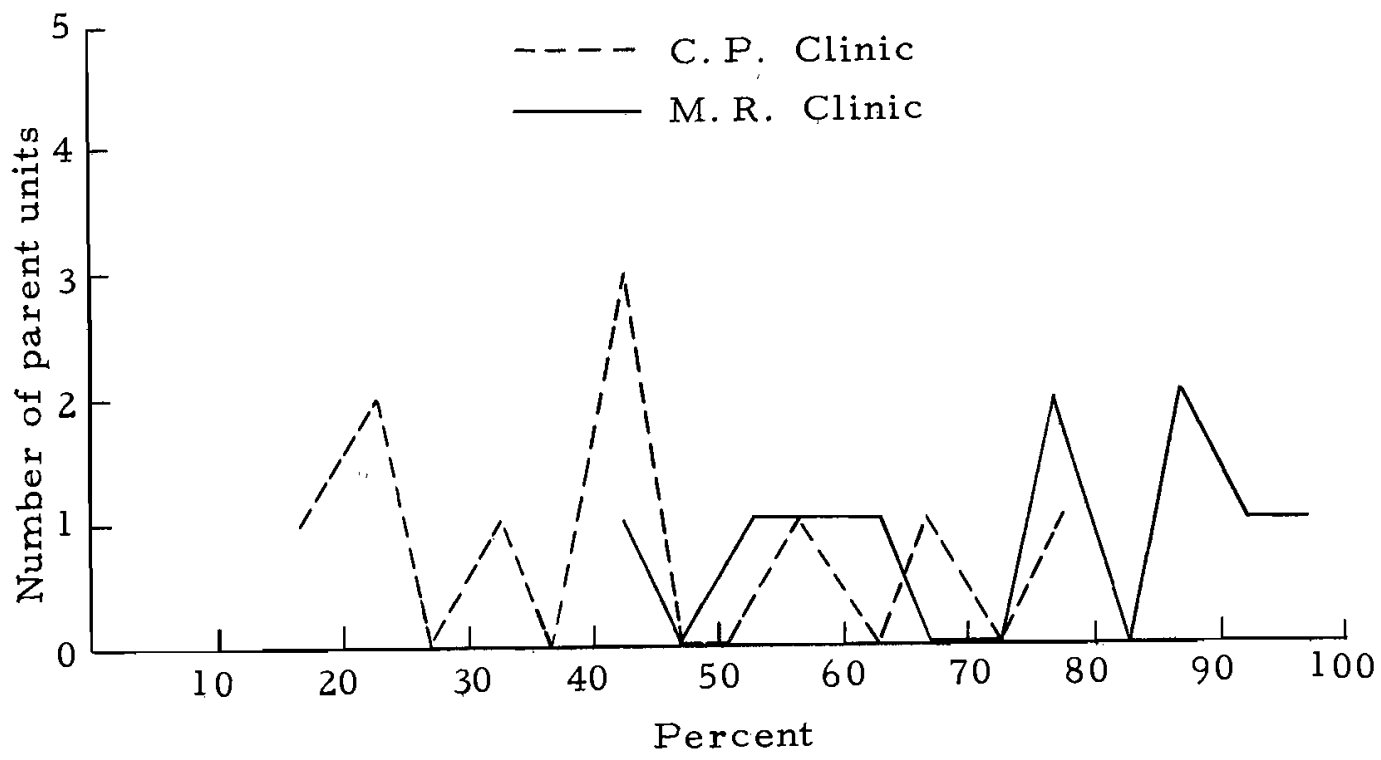

Figure 1. Percent of Baseline I imparted at parent confer ence (comparison between clinics). 


\section{The Amount of Recall from the Parent Conference}

A comparison was made between the Cerebral Palsy Clinic and the Mental Retardation Clinic of the percentage of information recalled from the parent conference six weeks later. The difference between the two clinics on the recall variable were statistically significant $(\mathrm{t}=2.10, \mathrm{df}=18, \mathrm{p}<.05)$

The results showed that multi-discipline conferencing resulted in much greater recall than single discipline conferencing. Figure 2 shows the amount of recall from the parent conference between the Cerebral Palsy Clinic and the Mental Retardation Clinic six weeks later. The frequency distribution of the percent value for each subject is listed in Appendix B (Table IX). The exact percentages of each subject is shown in Appendix B (Table X).

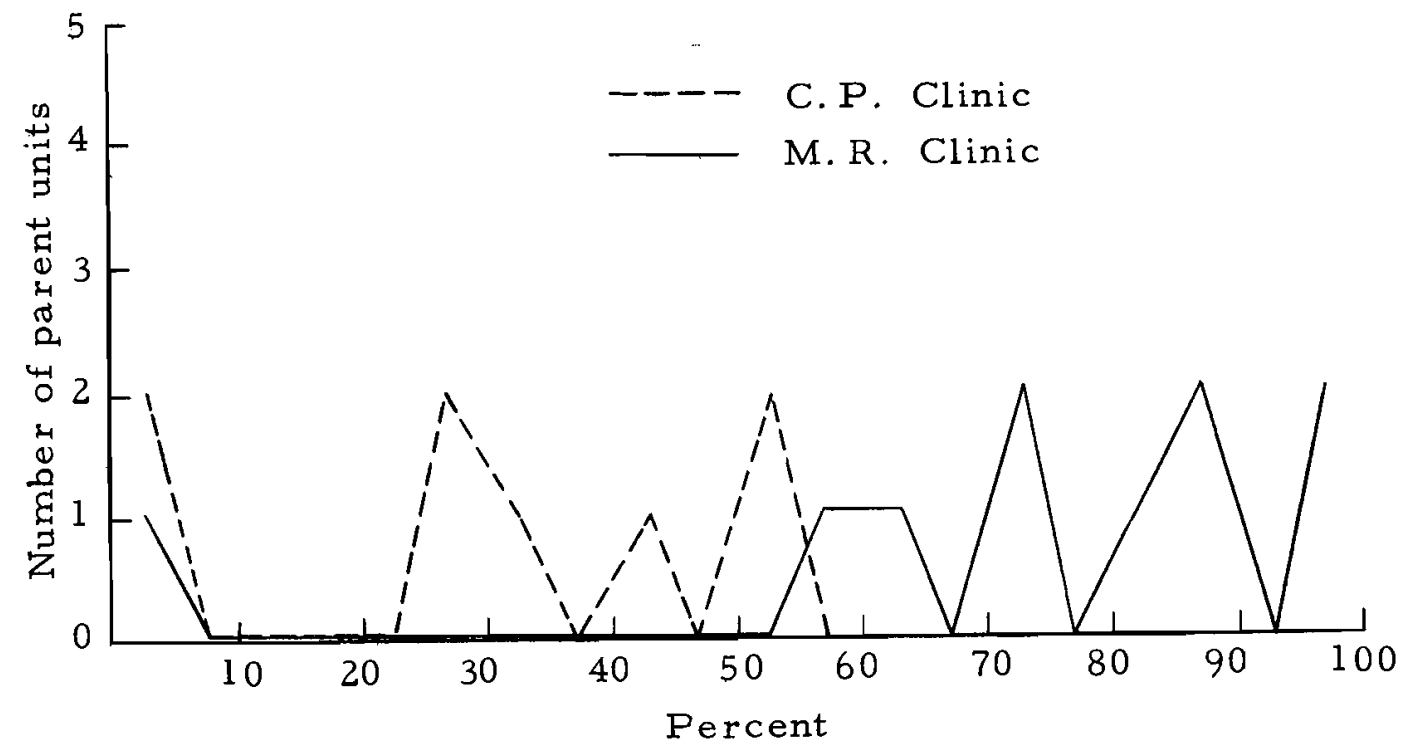

Figure 2. Percent of recall from Baseline II six weeks later (comparison between clinics). 
The Amount of Recall Compared to Essential Staffing Information

This comparison was also found to be statistically significant $(t=3.56, d f=18, p<.02)$. Although this particular comparison was not critical in terms of the analysis, since the parents did not attend the staffing, it has meaning for the staff of the clinics in emphasizing the informational loss. An illustration of this comparison is shown in Figure 3. The frequency distribution of the percent value for each subject is shown in Appendix B (Table XI). The exact percentages for each subject is listed in Appendix B (Table XII).

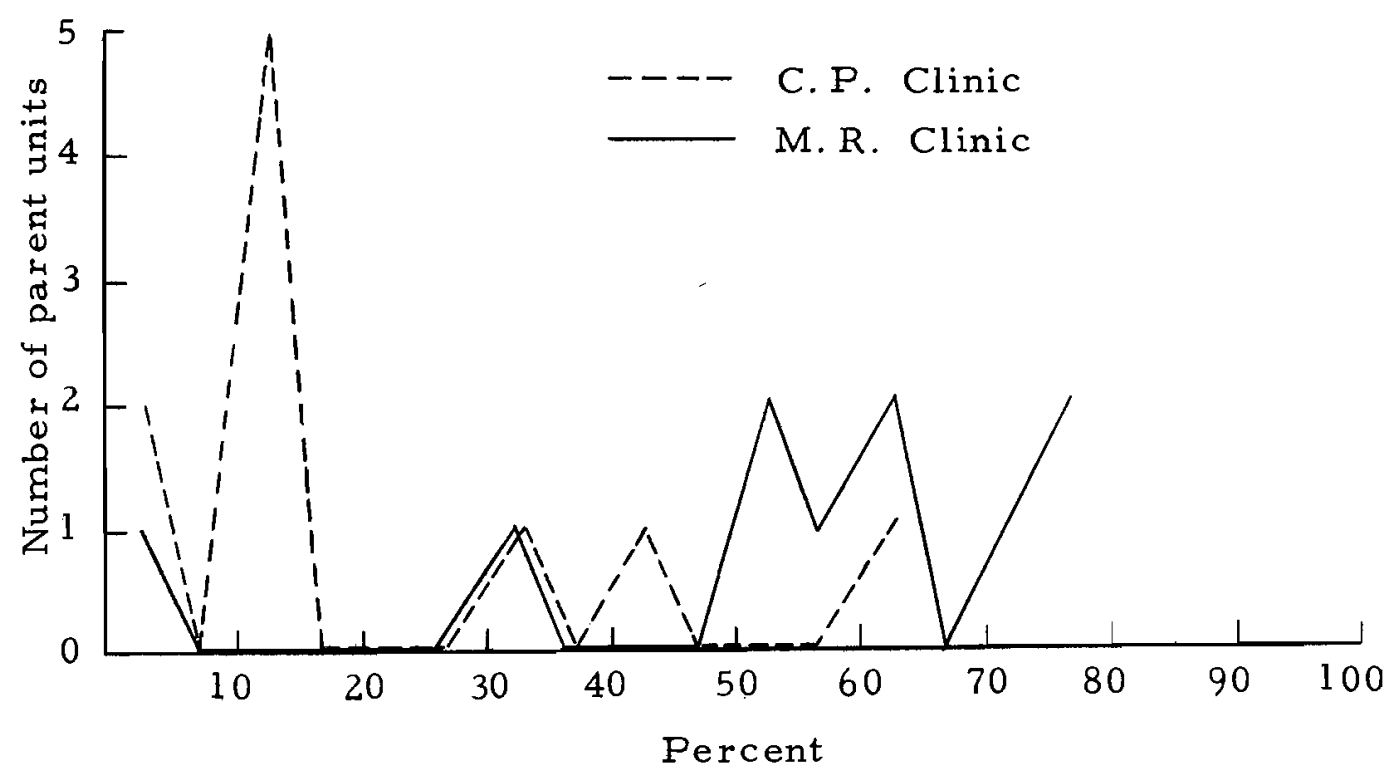

Figure 3. Percent of recall compared to Baseline I (comparison between clinics).

The diagnostic congruence of individual disciplines was also measured in terms of percentages. Descriptive data pertaining to a 
comparison of the two clinics is shown in Appendix B (Tables XIII and XIV).

Medicine and Psychology resulted in a remarkably higher rank than the participating disciplines. One could speculate that in both clinics intellectual capacity would have input; that is, value would be imparted to I. Q. scores by both disciplines. The percent values of the other disciplines reflected each clinic's team composition and specialization. For example, Education rated high in the Mental Retardation Clinic whereas Orthopedics was highly represented in the Cerebral Palsy Clinic. Social work barely appears in the Baseline II and recall data, however, input relative to Baseline $I$ information in Social work is largely incorporated into allied discipline reports and recommendations. In comparing recall with Baseline II information, all disciplines, with one exception, resulted in some loss of information, much more so in the Cerebral Palsy Clinic than in the Mental Retardation Clinic. Figure 4 shows the amount of recall compared with Baseline I information.

In comparing the clinics with regard to treatment recommendations, recall rated 80 percent in the Mental Retardation sample and 20 percent in the Cerebral Palsy Clinic.

Both clinics lost considerable diagnostic information in the communication process, however, the Cerebral Palsy Clinic data reflects a remarkably greater loss of information. 




Figure 4. Percent of recall information compared with Baseline I (comparison between clinics). 


\section{DISCUSSION}

The present study supported the hypotheses: (1) that a single post diagnostic conference results in a great loss in diagnostic recall by the parents. (2) That multi-discipline conferencing provides greater diagnostic recall than single discipline conferencing.

Approximately 75 percent of the disciplines rated high as participants in staff conferences, however, the amount of information recalled by the subjects was remarkably higher in the Mental Retardation Clinic than in the Cerebral Palsy Clinic.

A number of variables which were not observed in this study remain open to question as factors which might have influenced the statistical results. Such considerations give rise to a number of questions.

1. Is the amount of time spent in post staffing conferencing an adequate return for the amount of time invested in the process by the family?

The length of time of each parent conference was not measured for study purposes, however, the researcher observed that in general, the Mental Retardation Clinic parent conferences were considerably longer than those of the Cerebral Palsy Clinic. In the Cerebral Palsy Clinic a part-time visiting pediatrician conducts approximately 50 percent of the parent conferences which results in comparitively little 
time given to parent conferencing in those cases. Can one assume that a deliberate and comfortably paced conference results in greater retention of imparted information? Comments from the subjects implied that not enough time was given in the parent conference, i.e., "I was in there only five minutes or so"- - "They told me hardly anything." It is an interesting observation that in that case, more conference time than usual was given. At the time of the follow up interview, the parent seemed totally unaware of the recommendations for the child. Therapeutic intervention was indicated in that case and like situations which necessarily requires multiple conferencing and time consuming efforts on the part of the clinic. With regard to the parent conference, some other responses were: "I had to keep my composure until I got home--I had to drive."; and, "After the conference I felt like a big void." Another parent described her husband as appearing to be in good emotional control in the conference when they were instructed to have their child's skull $x$-rayed. As they were driving away she was surprised to see tears streaming down her husband's face, followed by sobs, fearing that their child was sus pected of having a brain tumor. In behalf of the parents, it should be noted that the parent conference takes place immediately following one and one-half days of consecutive examinations. If the mind can absorb only as much as the seat can endure, what effect does this have on recall? 
2. Was the diagnostic information heard and understood?

Many subjects appeared to understand the contents of the parent conferences, however the results of this study indicate that the parents' diagnostic recall was diminished, even though in most of the parent conferences the professional did make a conscious effort to avoid professional jargon. Usually, toward the end of the parent conference, an opportunity was given for the parents to ask questions. Seemingly, this was ineffective because the parents were either preoccupied with their feelings, unable to think clearly, or unprepared to ask helpful questions or are not comfortable in communicating with physicians. There were few instances where feedback was encouraged. This process would give the professional a checking system which would clarify whether or not the information was heard or understood by the parent.

3. What are the implications for multiple conferencing?

The results of the present study suggest that multi-discipline conferencing is much more effective than single discipline conferencing. However, the results also indicate that even with the more effective approach of imparting diagnostic information, there is considerable loss of information. It follows that a strong case has been made for additional services beyond the single conference. Not only is there a need on the part of the parent to be given opportunity to gain an intellectual understanding but to work through, in a treatment 
sense, all of the anger, resentment, fear and insecurity that the trauma of parenting a defective child brings to bear upon the family.

4. How effective is the role of the case coordinator?

Considering that the Mental Retardation Clinic team has a "case coordinator" whose function it is to preside over the team meeting and act as clinic representative to the parents, it was interesting to find out that few of the subjects of this study were aware that there was such a person. Three subjects in the Mental Retardation Clinic named staff members as coordinators. Two were correct, those being a nurse and a social worker. The third coordinator was guessed to be the social worker when in fact it was the dentist. Within the Cerebral Palsy Clinic, Medicine (pediatrician) is consistantly the team representative in the parent conference. In taking a survey of that clinic, there were four subjects who attempted to name a coordinating person. None of them named the pediatrician. Those named were psychologist, receptionist, and two named the social worker.

An additional observation in evaluating the diagnostic consultation process was that very often the child-patient was excluded from the parent conference, in terms of direct communication. A few of the child patients were given direct consultation however, in one instance, where a strong recommendation was made by the team for the team representative to talk with an apprehensive, evasive child the purpose of the evaluation, that was not done in the subsequent 
parent-child conference. Rautman and Rautman (1948) made a pointed statement about adult-child communication. "Not only must a child be trained to meet other children and adults gracefully, but a great many adults need help in meeting and talking with children" (p. 631). One of the problems encountered when a child is introduced to an adult is mutual panic which may result in the adult taking over the whole show or conversely, may be struck speechless. Whatever the reason in the above stated case, the avoidance was conspicuous, and a shortchanging of service occurred which neither the patient nor the agency could afford.

Children were present in a number of parent conferences which proved to be distracting. It follows that unless there is a specific purpose for the child to be present at the parent conference, it should be to the advantage of all concerned for him to be excluded, in a physical sense. 


\section{CHAPTER V}

\section{SUMMARY}

The purpose of this study was to measure diagnostic congruence: That is, the congruence between diagnostic information imparted at a conference and the recall of the diagnostic information at a later date.

The setting for the present study was the Crippled Children's Division of the University of Oregon Medical School. The sample was taken from two clinics within the Crippled Children's Division. There were ten families from the Cerebral Palsy Clinic and ten from the Mental Retardation Clinic; each of which had one or more children who were evaluated for cerebral palsy or mental retardation by the clinic teams. The study design was the one shot case study. Sample groups were studied in which the observations were attributed to a prior situation, the parent conference.

The data was collected by 1) recording the diagnostic information presented by the clinic team members 2) recording the diagnostic information which was imparted to the parents and 3) recording the information retained by the parents from the parent conference.

Areas of measurement were 1) Comparing the amount of information that was imparted to the parents from the staffing session. 
2) Comparing the amount of recall six weeks later with Baseline II (parent conference) and 3) Comparing the amount of recall information with that of the Baseline I (staffing). Another comparison was made of the above measures in relation to the individual disciplines of each clinic. The purpose of the study was to measure the effectiveness of one session conferencing and also to compare the effectiveness of single discipline conferencing to that of multi-discipline conferencing.

The intra-clinic findings in the Cerebral Palsy Clinic demonstrated that less than one-half of the staffing information which was determined to be essential was presented at the parent conference. Less than one-half of the parent conference information was recalled six weeks later. The parents recall represented less than one-fifth of the total essential staffing information. The intra-clinic findings in the Mental Retardation Clinic demonstrated that about three-fourths of the essential staffing information was presented at the parent conference. Slightly less than three-fourths of the parent conference information was recalled six weeks later. About one-half of the essential staffing information was presented in recall.

The inter-clinic comparisons showed that (1) multi-discipline conferencing imparted a much higher percentage of essential staffing information; (2) multi-discipline conferencing resulted in much greater recall than single discipline conferencing; and, (3) both clinics experienced a significant loss of diagnostic information in the communication process. 


\section{BIBLIOGRAPHY}

Abruzzinni, P., Antossi, A., Ferracuti, F., Lazzari, R., Livi, C. and Zaccone - Derossi, F., "Results of an Experimental Investigation on Memory and Comprehension of News Content in Daily Radio Broadcasts," Bollettino di Psicologia Applicata, 1964. No. 61-62, pp. 55-57.

Aiken, L.H., "Patient Problems Are Problems in Learning," American Journal of Nursing, Vol. 70, September, 1970. pp. $1916-1918$.

Anderson, Kathryn A., 'The 'Shopping' Behavior of Parents of Mentally Retarded Children: The Professional Persons' Role, " Mental Retardation, Vol. 9, No. 4, August, 1971. pp. 3-5.

Ausube1, David P. and Youssef, Mohamed, "The Effect of Spaced Repetition on Meaningful Retention," Journal of General Psychology, Vol. 73, 1965. pp. 147-150.

Baron, Naomi, "Memory and Emotion," American Psychologist, Vol. 17, 1962. pp. 146-148.

Beck, Helen L., "Counseling Parents of Retarded Children," Children, Vol. 6, 1959. pp. 225-230.

Block, J.E., "Personality Characteristics Associated with Fathers' Attitudes Toward Child Rearing," Child Development, Vol. 26, 1955. pp. $41-48$.

Campbell, D.T., "Factors Relevant to the Validity of Experiments in Social Settings," Psychology Bulletin, Vol. 54, 1957. pp. 297 311 .

Covert, Cathy, Mental Retardation - A Handbook for the Primary Physician. In: The Journal of the American Medical Association, Vol. 191, No. 3, January 18, 1965. 
Dodge, J.S., "Factors Related to Patients' Perception of Their Cognitive Needs," Nursing Research, Vol. 18, November December, 1969. pp. 502-513.

Doll, Edgar A., "Counselling Parents of Severely Mentally Retarded Children," Journal of Clinical Psychology, Vol. 9, 1953. pp. $114-117$.

Ferguson, Janet L. and Tweed, Russel, "A Study of Families with Stress Related to the Care of Children with Myelomeningocele, " Master's Thesis. Portland, Portland State University, 1971.

Fitzgerald, O.R., "A Holistic View of Man - Fantasy or Fact?," Medical Annals of the District of Columbia, Vol. 39, Number 10, October, 1970. pp. 574-575.

Gang, S. et al., "An Experiment in Combined Learning," Practitioner, 206, March 1971. pp. 395-398.

Garfield, Sol L. and Helper, Malcolm M., "Parental Attitudes and Socio-economic Status," Journal of Clinical Psychology, Vol. 18, 1962. pp. $171-175$.

Hare, E.H., Laurence, K. M. , Payne, Helly and Rawnsley, K., "Spina Bifida Cystica and Family Stress," British Medical Journal, 24 September, No. 2, 1966. pp. 757-760.

Hare, E.H. and Laurence, K.M., "The Parents of the Child with Spina Bifida Cystica," Pediatrics Digest, February 1969. pp. $26-35$.

Hegrenes, Jack R., "The Competence of Persons Institutionalized During Infancy." Doctoral Dissertation. Chicago, University of Chicago, 1970.

Jannis, P.T., "The Need for Intervention: A Variable in Psychotherapy Research, "Archives of General Psychiatry, Chicago, Vol. 23, September, 1970. pp. $284-287$.

King, David J. and Schultz, Duane P., "Additional Observations on Scoring the Accuracy of Written Recall, " Psychological Record, Vol. 10, 1960. pp. 20-209.

Lemkau, Paul V., "The Influence of Handicapping Conditions on Child Development," Children, March-April, 1961. pp. 43-47. 
Lillywhite, Herold, "General Concepts of Communication," Journal of Pediatrics, Vol. 62, 1963. pp. 5-10.

Mowbray, G.H., "Perception and Retention of Verbal Information Presented During Auditory Shadowing, " Journal of the Accoustical Society of America, Vol. 36, No. 8, 1964. pp. $1459-1464$.

Murdock, Bennet B., "Response - factors in Learning and Transfer," America's Journal of Psychology, Vol. 73, 1960. pp. 355-369.

Murdock, Bennet B., Jr., and Babick, Arthur J., "The Effect of Repetition on the Retention of Individual Words, "American Journal of Psychology, Vol. 74, 1961. pp. 596-601.

National Conference on Homemaker Services (Report, 1964)

Oldham, R.K., "Terminal Cancer - a Patient Oriented Approach," Journal of Tennessee Medical Association, Vol. 63, March, 1970. pp. 206-208.

Olshansky, Simon, "Chronic Sor row': A Response to Having a Mentally Defective Child," Social Casework, Vol. XLIII, No. 4, April 1962. pp. 190-193.

Patterson, Letha L., "Some Pointers for Professionals," Children, January-February, 1956. pp. $13-17$.

Pearson, Paul H., and Menefee, Allen R., "Medical and Social Management of the Mentally Retarded," G.P., Vol. XXXI, No. 2, February, 1965. pp. 78-90.

Perlman, Helen H., Social Casework: A Problem-Solving Process, The University of Chicago Press, Chicago, 1957.

Rapoport, Lydia, "Working with Families in Crisis: An Exploration in Resentive Intervention, "Social Work, Vol VII, No. 3, July, 1962. pp. $48-56$.

Rautman, Emily and Rautman, Arthur, "Talking to a Child," Mental Hygiene, Vol. XXXII, No. 4, October, 1948. pp.631-637.

Reynolds, James H. and Glaser, Robert, "Effects of Repetition and Spaced Review Upon Retention of a Complex Learning Task, " Journal of Educational Psychology, Vol. 55, No. 5, 1964. pp. 297-308. 
Schaefer, Earl S., and Bell, Richard Q., "Development of a Parental Attitude Research Instrument," Child Development, Vol. 29, 1958. pp. 339-361.

Schaefer, Earl S., and Bell, Richard Q., "Patterns of Attitudes Toward Child Rearing and the Family," Journal of Abnormal Social Psychology, Vol. 54, 1957. pp. 391-395.

Scheerenberger, R.C., "Generic Services for the Mentally Retarded and Their Families," Mental Retardation, December, 1970. pp. $10-16$.

Schulman, J.L., "Management of the Irate Parent," Journal of Pediatrics, Vol. 77, August, 1970. pp. 338-340.

Shotland, Leonard, "Social Work Approach to the Chronically Handicapped and Their Families," Social Work, Vol. VIII, No. 4, October, 1064. pp. 68-75.

Silberstein, Edward B., "Implications of 'Uncooperative', " $\underline{\text { New }}$ England Journal of Medicine, Vol. 283, 17 December, 1970. p. 1413 .

Stephens, Wyatt, "Interpreting Mental Retardation to Parents in a Multi-Diagnostic Center," Mental Retardation, Vol. 7, No. 6, December, 1969. pp. $57-59$.

Strupp, H.H., "Toward a Specification of Teaching and Learning in Psychotherapy, " Archives of General Psychiatry, Vol. 21, 1969. pp. $203-212$.

Tudway, A.J., "A Common Problem in Practice," Journal of the Royal College of General Practitioners, Vol. 19, February, 1970. pp. $120-122$.

Wallace, Helen M., "Coordinating Health Services for Handicapped Children, " Children, January-February, 1958. pp. 20-29.

Wike, Shar on S., and Wike, Edward L., "A Test of the Spew Hypothesis Using Intralist Repetition and a Free-Recall Task, " Psyhonomic Science, Vol. 19, No. 6, 1970. pp. 349-350. 
Witmer, Helen L. and Katinsky, Ruth, "Personality in the Making," The Fact Finding Report of the Mid-Century White House Conference on Children and Youth, Harper and Bros., New York, 1952. pp. $207-209$.

Zuckerman, Marvin, Barrett, Beatrice and Bragiel, R. M., "The Parental Attitudes of Parents and Child Guidance Cases: I. Comparisons with Normals, Investigation of Socio-Economic and Family Constellation Factors and Relation to Parents Reactions to the Clinic," Child Development, Vol. 31, 1960. pp. 401-417.

Zwerling, Irael, "Initial Counseling of Parents With Mentally Retarded Children, "Journal of Pediatrics, St. Louis, Vol.44, No. 4, April 1954. pp. 469-479. 


\section{APPENDIX}

\section{SUPPLEMENTARY TABLES}


TABLE VII

FREQUENCY DISTRIBUTION OF BASELINE I PRESENTED AT PARENT CONFERENCE (BASELINE II)

$$
\mathrm{N}=20
$$

\begin{tabular}{|c|c|c|}
\hline $\begin{array}{l}\text { Class } \\
\text { Interval }\end{array}$ & $\begin{array}{c}\text { Cerebral Palsy } \\
\text { Clinic }\end{array}$ & $\begin{array}{c}\text { Mental Retardation } \\
\text { Clinic }\end{array}$ \\
\hline $0-4.99$ & 0 & 0 \\
\hline $5-9.99$ & 0 & 0 \\
\hline $10-14.99$ & 0 & 0 \\
\hline $15-19.99$ & 1 & 0 \\
\hline $20-24.99$ & 11 & 0 \\
\hline $25-29.99$ & 0 & 0 \\
\hline $30-34.99$ & 1 & 0 \\
\hline $35-39.99$ & 0 & 0 \\
\hline $40-44.99$ & 111 & 1 \\
\hline $45-49.99$ & 0 & 0 \\
\hline $50-54.99$ & 0 & 1 \\
\hline $55-59.99$ & 1 & 1 \\
\hline $60-64.99$ & 0 & 1 \\
\hline $65-69.99$ & 1 & 0 \\
\hline $70-74.99$ & 0 & 0 \\
\hline $75-79.99$ & 1 & 11 \\
\hline $80-84.99$ & 0 & 0 \\
\hline $85-89.99$ & 0 & 11 \\
\hline $90-94.00$ & 0 & 1 \\
\hline \multirow[t]{2}{*}{$95-100.00$} & 0 & 1 \\
\hline & $n=10$ & $\mathrm{n}=10$ \\
\hline
\end{tabular}


TABLE VIII

EXACT SUBJECT PERCENTAGES OF BASELINE I PRESENTED AT PARENT CONFERENCE

\begin{tabular}{ccc}
\hline Subject & $\begin{array}{c}\text { Mental Retardation } \\
\text { Clinic }\end{array}$ & $\begin{array}{c}\text { Cerebral Palsy } \\
\text { Clinic }\end{array}$ \\
\hline & $\frac{\text { Percent }}{1}$ & $\frac{\text { Percent }}{42}$ \\
2 & 78 & 56 \\
3 & 100 & 22 \\
4 & 60 & 66 \\
5 & 89 & 44 \\
6 & 57 & 78 \\
7 & 88 & 44 \\
8 & 75 & 22 \\
9 & 44 & 18 \\
10 & 50 & 33 \\
\hline & 88 & $\bar{X}=42.5$ \\
& $\bar{X}=72.80$ & $s=18.79$ \\
\hline
\end{tabular}


TABLE IX

FREQUENCY DISTRIBUTION OF PERCENT OF BASELINE II RECALLED SIX WEEKS LATER

$$
\mathrm{N}=20
$$

\begin{tabular}{lcc}
\hline $\begin{array}{c}\text { Class } \\
\text { Interval }\end{array}$ & $\begin{array}{c}\text { Cerebral Palsy } \\
\text { Clinic }\end{array}$ & $\begin{array}{c}\text { Mental Retardation } \\
\text { Clinic }\end{array}$ \\
\hline $0-4.99$ & 0 & 0 \\
$5-9.99$ & 0 & 0 \\
$10-14.99$ & 0 & 0 \\
$15-19.99$ & 1 & 0 \\
$20-24.99$ & 11 & 0 \\
$25-29.99$ & 0 & 0 \\
$30-34.99$ & 1 & 0 \\
$35-39.99$ & 0 & 0 \\
$40-44.99$ & 11 & 1 \\
$45-49.99$ & 0 & 0 \\
$50-54.99$ & 0 & 1 \\
$55-59.99$ & 1 & 1 \\
$60-64.99$ & 0 & 0 \\
$65-69.99$ & 1 & 0 \\
$70-74.99$ & 0 & 11 \\
$75-79.99$ & 1 & 0 \\
$80-84.99$ & 0 & 11 \\
$85-89.99$ & 0 & 1 \\
$90-94.99$ & 0 & 10 \\
$95-100.00$ & 0 & 10 \\
50 & 0 & 1 \\
\hline
\end{tabular}


TABLE $X$

EXACT SUBJECT PERCENTAGES OF RECALL OF BASELINE II SIX WEEKS LATER

\begin{tabular}{ccc}
\hline Subject & $\begin{array}{c}\text { Mental Retardation } \\
\text { Clinic }\end{array}$ & $\begin{array}{c}\text { Cerebral Palsy } \\
\text { Clinic }\end{array}$ \\
\hline & $\begin{array}{c}\text { Percent } \\
1\end{array}$ & $\begin{array}{c}\text { Percent } \\
2\end{array}$ \\
3 & 71 & 0 \\
4 & 83 & 100 \\
5 & 88 & 50 \\
6 & 100 & 100 \\
7 & 71 & 25 \\
8 & 83 & 43 \\
9 & 0 & 25 \\
10 & 60 & 50 \\
& 57 & $\bar{X}=42.60$ \\
& $\overline{\mathrm{X}}=71.30$ & $\mathrm{~s}=33.34$ \\
\hline
\end{tabular}


TABLE XI

FREQUENCY DISTRIBUTION OF PERCENT OF RECALL COMPARED WITH BASELINE I

$\mathrm{N}=20$

\begin{tabular}{ccc}
\hline $\begin{array}{c}\text { Class } \\
\text { Interval }\end{array}$ & $\begin{array}{c}\text { Cerebral Palsy } \\
\text { Clinic }\end{array}$ & $\begin{array}{c}\text { Mental Retardation } \\
\text { Clinic }\end{array}$ \\
\hline $0-4.99$ & 11 & 1 \\
$5-9.99$ & 0 & 0 \\
$10-14.99$ & 1 & 0 \\
$15-19.99$ & 0 & 0 \\
$20-24.99$ & 0 & 0 \\
$25-29.99$ & 0 & 0 \\
$30-34.99$ & 1 & 1 \\
$35-39.99$ & 0 & 0 \\
$40-44.99$ & 1 & 0 \\
$45-49.99$ & 0 & 11 \\
$50-54.99$ & 0 & 1 \\
$55-59.99$ & 0 & 1 \\
$60-64.99$ & 0 & 0 \\
$65-69.99$ & 1 & 1 \\
$70-64.99$ & 0 & 11 \\
$75-79.99$ & 0 & 0 \\
$80-84.99$ & 0 & 0 \\
$85-89.99$ & 0 & 0 \\
$90-94.99$ & 0 & 10 \\
$95-100.00$ & 0 & 0 \\
5 & 0 & 0 \\
\hline
\end{tabular}


TABLE XII

EXACT SUBJECT PERCENTAGES OF RECALL COMPARED WITH BASELINE I

\begin{tabular}{ccc}
\hline Subject & $\begin{array}{c}\text { Mental Retardation } \\
\text { Clinic }\end{array}$ & $\begin{array}{c}\text { Cerebral Palsy } \\
\text { Clinic }\end{array}$ \\
\hline & $\frac{\text { Percent }}{18}$ & $\frac{\text { Percent }}{1}$ \\
2 & 78 & 0 \\
3 & 71 & 44 \\
4 & 50 & 11 \\
5 & 77 & 66 \\
6 & 57 & 11 \\
7 & 63 & 33 \\
8 & 63 & 11 \\
9 & 0 & 11 \\
10 & 30 & 0 \\
& 50 & $\bar{X}=19.80$ \\
& $\bar{X}=53.80$ & $s=20.16$ \\
\hline
\end{tabular}


TABLE XIII

CEREBRAL PALSY CLINIC: PERCENT OF PARTICIPATION OF INDIVIDUAL DISCIPLINES IN CLINIC SAMPLE. PERCENT OF BASELINE I IMPARTED AT PARENT CONFERENCE; PERCENT OF INFORMATION RETAINED FROM

PARENT CONFERENCE AND PERCENT OF INFORMATION RETAINED, COMPARED WITH BASELINE I

\begin{tabular}{|c|c|c|c|c|}
\hline Discipline & $\begin{array}{c}\text { Baseline } \\
\text { I }\end{array}$ & $\begin{array}{c}\text { Baseline } \\
\text { II }\end{array}$ & $\begin{array}{c}\text { Recall } \\
\text { from } \\
\text { Baseline } \\
\text { II }\end{array}$ & $\begin{array}{c}\text { Recall } \\
\text { Compared } \\
\text { to Baseline } \\
\text { I }\end{array}$ \\
\hline & $\underline{\text { Percent }}$ & $\underline{\text { Percent }}$ & Percent & Percent \\
\hline Medicine & 100 & 70 & 43 & 30 \\
\hline Social work & 100 & 0 & 0 & 0 \\
\hline Speech and audiology & 100 & 20 & 5 & 10 \\
\hline Opthalmology & 20 & 0 & 0 & 0 \\
\hline Occupational therapy & 100 & 40 & 25 & 10 \\
\hline Physical therapy & 100 & 10 & 100 & 10 \\
\hline Psychology & 100 & 80 & 38 & 30 \\
\hline Neurology & 20 & 0 & 0 & 0 \\
\hline Orthopedics & 80 & 75 & 50 & 38 \\
\hline Dentistry & 90 & 33 & 100 & 33 \\
\hline Nursing & 10 & 0 & 0 & 0 \\
\hline Education & 30 & 67 & 50 & 33 \\
\hline Recommendations & 100 & 70 & 29 & 20 \\
\hline
\end{tabular}


TABLE XIV

MENTAL RETARDATION CLINIC: PERCENT OF PARTICIPATION OF INDIVIDUAL DISCIPLINES IN CLINIC SAMPLE. PERCENT OF

BASELINE I IMPAR TED AT PARENT CONFERENCE;

PER CENT OF INFORMATION RETAINED FROM

PARENT CONFERENCE AND PERCENT OF

INFORMATION RETAINED, COMPARED

WITH BASELINE I

\begin{tabular}{|c|c|c|c|c|}
\hline Discipline & $\begin{array}{c}\text { Baseline } \\
\text { I }\end{array}$ & $\begin{array}{c}\text { Baseline } \\
\text { II }\end{array}$ & $\begin{array}{c}\text { Recall } \\
\text { from } \\
\text { Baseline } \\
\text { II }\end{array}$ & $\begin{array}{c}\text { Recall } \\
\text { Compared } \\
\text { to Baseline } \\
\text { I }\end{array}$ \\
\hline & Percent & Percent & Percent & Percent \\
\hline Medicine & 100 & 100 & 80 & 80 \\
\hline Social work & 100 & 40 & 100 & 40 \\
\hline Speech and audiology & 100 & 70 & 57 & 40 \\
\hline Opthalmology & 20 & 100 & 100 & 100 \\
\hline Occupational the rapy & 80 & 63 & 40 & 25 \\
\hline Physical therapy & 70 & 57 & 75 & 43 \\
\hline Psychology & 100 & 90 & 100 & 90 \\
\hline Neurology & 0 & 0 & 0 & 0 \\
\hline Orthopedics & 0 & 0 & 0 & 0 \\
\hline Dentistry & 80 & 63 & 20 & 13 \\
\hline Nursing & 30 & 33 & 0 & 0 \\
\hline Education & 80 & 63 & 100 & 63 \\
\hline Recommendations & 100 & 100 & 80 & 80 \\
\hline
\end{tabular}

